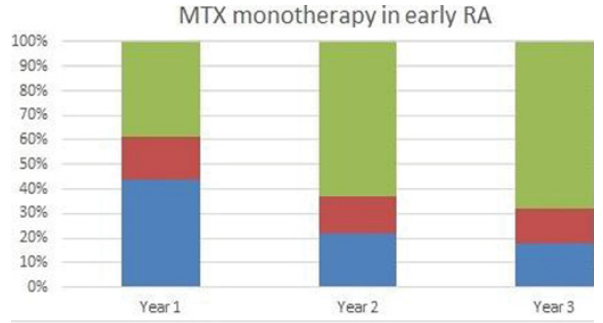

$\mathrm{MTX}+\mathrm{HCQ}+$ Steroids in early RA

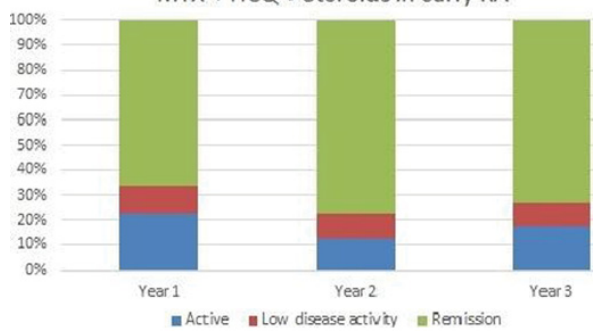

practice in early rheumatoid arthritis patients: results from the DREAM registry. Art Res \& Ther 2016: 10.1186/s13075-016-0962-9.

Disclosure of Interest: None declared

DOI: 10.1136/annrheumdis-2017-eular.3892

\section{OP0229 EFFECT OF BASELINE SERUM CRP LEVELS ON CLINICAL EFFICACY IN RHEUMATOID ARTHRITIS PATIENTS TREATED WITH FILGOTINIB: POST-HOC ANALYSIS FROM TWO PHASE 2B STUDIES}

R. Westhovens ${ }^{1}$, A. Kavanaugh ${ }^{2}$, C. Jamoul ${ }^{3}$, C. Tasset $^{3}$, P. Harrison ${ }^{3}$, A. Van der Aa ${ }^{3} \cdot{ }^{1}$ Rheumatology, KU Leuven, University Hospitals, Leuven, Belgium; ${ }^{2}$ University of California, la Jolla, United States; ${ }^{3}$ Galapagos NV, Mechelen, Belgium

Background: Filgotinib (GLPG0634, GS-6034) is an oral, selective JAK1 inhibitor that has shown a favorable safety and efficacy profile both as add-on to methotrexate (MTX) and as monotherapy in two 24-week placebo-controlled phase $2 \mathrm{~B}$ studies in active rheumatoid arthritis (RA) patients with inadequate response to MTX (MTX-IR) ${ }^{1,2}$.

Objectives: To assess effect of baseline serum CRP levels on clinical efficacy in MTX-IR RA patients treated with filgotinib.

Methods: Patients were randomized in a double blind manner to placebo (PBO) or one of 3 daily doses of filgotinib $(50 \mathrm{mg}, 100 \mathrm{mg}$ or $200 \mathrm{mg}$ ) for 24 weeks. In the DARWIN 1 study, filgotinib on the background of MTX was evaluated as once (QD) or twice daily treatment. In the DARWIN 2 study once-daily filgotinib was assessed as monotherapy. The inclusion criterion for CRP was amended during the studies and decreased over time from $13.5 \mathrm{mg} / \mathrm{L}$ to $6.3 \mathrm{mg} / \mathrm{L}$. This post hoc analysis included patients treated with the selected Phase 3 filgotinib doses, $100 \mathrm{mg}$ and $200 \mathrm{mg}$ QD, and PBO. Efficacy outcomes were analyzed by baseline CRP level (low: $\leq 9 \mathrm{mg} / \mathrm{L}$ and high: $>9 \mathrm{mg} / \mathrm{L}$, with $9 \mathrm{mg} / \mathrm{L}$ as ULN).

Results: Baseline disease activity was high, with mean DAS28(CRP) scores of 5.6 and 5.7 in the low CRP subgroups for DARWIN 1 and DARWIN 2, respectively, and 6.3 in the high CRP subgroups for both studies. Mean CRP levels at baseline were elevated $(16.3-35.3 \mathrm{mg} / \mathrm{L})$. In both low and high CRP subgroups, patients on filgotinib $100 \mathrm{mg}$ or $200 \mathrm{mg}$ QD for 12 weeks showed efficacy over PBO, as measured by change from baseline in DAS28(CRP), CDAI and HAQ-DI, and ACR20 (Table 1). Despite slight numerical differences, baseline CRP level had no consistent effect on filgotinib efficacy, neither for endpoints including CRP (DAS28(CRP) or ACR20) nor for endpoints not including CRP (CDAI). Results were similar across both studies.

Table 1. Change from baseline in key efficacy parameters at Week 12 by CRP subgroup (mean (SE))

\begin{tabular}{|c|c|c|c|c|c|c|}
\hline & \multicolumn{3}{|c|}{ DARWIN 1} & \multicolumn{3}{|c|}{ DARWIN 2} \\
\hline & PBO & $\begin{array}{c}\text { Filgotinib } \\
\text { 100mg QD }\end{array}$ & $\begin{array}{c}\text { Filgotinib } \\
200 \mathrm{mg} \text { QD }\end{array}$ & PBO & $\begin{array}{c}\text { Filgotinib } \\
100 \mathrm{mg} Q D\end{array}$ & $\begin{array}{l}\text { Filgotinib } \\
200 \mathrm{mg} \text { QD }\end{array}$ \\
\hline \multicolumn{7}{|c|}{ Low CRP subgroup ( $\leq 9 \mathrm{mg} / \mathrm{L}$ ) } \\
\hline $\mathrm{N}$ & 33 & 25 & 15 & 11 & 20 & 20 \\
\hline \multicolumn{7}{|l|}{ DAS28 } \\
\hline (CRP) & $-1.2(0.30)$ & $-2.2(0.24)$ & $-2.2(0.32)$ & $-0.9(0.55)$ & $-2.1(0.33)$ & $-2.3(0.25)$ \\
\hline CDAI & $-18.3(3.52)$ & $-23.7(2.66)$ & $-25.1(3.45)$ & $-11.5(6.19)$ & $-25.8(3.53)$ & $-27.4(3.05)$ \\
\hline HAQ-DI & $-0.21(0.121)$ & $-0.76(0.133)$ & $-0.64(0.100)$ & $-0.12(0.163)$ & $-0.74(0.172)$ & $-0.74(0.158)$ \\
\hline \multicolumn{7}{|c|}{ High CRP subgroup (>9 mg/L) } \\
\hline $\mathrm{N}$ & 53 & 60 & 71 & 61 & 50 & 49 \\
\hline DAS28 & $-1.2(0.15)$ & $-2.3(0.19)$ & $-2.5(0.15)$ & $-1.0(0.17)$ & $-2.0(0.19)$ & $-2.3(0.19)$ \\
\hline CDAI & $-15.6(2.04)$ & $-23.8(2.08)$ & $-25.5(1.67)$ & $-11.7(1.94)$ & $-23.3(2.38)$ & $-24.1(2.12)$ \\
\hline HAQ-DI & $-0.49(0.080)$ & $-0.61(0.087)$ & $-0.78(0.076)$ & $-0.25(0.074)$ & 0.65 & $-0.74(0.086)$ \\
\hline \multicolumn{7}{|c|}{ ACR20 by subgroup, $n(\%)$} \\
\hline Low CRP & $15(45 \%)$ & $19(76 \%)$ & $10(67 \%)$ & $2(18 \%)$ & $13(65 \%)$ & $16(80 \%)$ \\
\hline High CRP & $23(43 \%)$ & $35(58 \%)$ & $49(69 \%)$ & $19(31 \%)$ & $33(66 \%)$ & $34(69 \%)$ \\
\hline
\end{tabular}

Conclusions: Post hoc analysis of two Phase 2B studies in MTX-IR RA patients suggests that filgotinib treatment once daily at $100 \mathrm{mg}$ and $200 \mathrm{mg}$ both on the background of MTX and as monotherapy is consistently associated with improved clinical outcomes compared to placebo, regardless of baseline CRP levels.

References:

[1] Westhovens R et al. Ann Rheum Dis 2016:0:1-11.

[2] Kavanaugh A et al. Ann Rheum Dis 2016;0:1-11.

Disclosure of Interest: R. Westhovens Grant/research support from: Roche, Consultant for: Galapagos, Speakers bureau: BMS, A. Kavanaugh Consultant for: Galapagos, Pfizer, AbbVie, Amgen, Celgene, Janssen, Novartis, Eli Lilly, UCB, C. Jamoul Employee of: Galapagos NV, C. Tasset Employee of: Galapagos NV, P. Harrison Employee of: Galapagos NV, A. Van der Aa Employee of: Galapagos NV DOI: 10.1136/annrheumdis-2017-eular.5428

\section{OP0230 THE EFFECTIVENESS OF ZOSTER VACCINE IN RA PATIENTS SUBSEQUENTLY TREATED WITH TOFACITINIB}

K.L. Winthrop ${ }^{1}$, A. Wouters ${ }^{2}$, E.H. Choy ${ }^{3}$, C. Nduaka ${ }^{4}$, P. Biswas ${ }^{2}$, L. Wang $^{5}$, J. Hodge $^{2}$, I. Lazariciu ${ }^{6}$, K. Soma ${ }^{5}$, C.F. Mojcik ${ }^{2}$, W.F.C. Rigby ${ }^{7} .{ }^{1}$ Oregon Health and Science University, Portland, OR; ${ }^{2}$ Pfizer Inc, New York, NY, United States; ${ }^{3}$ CREATE Center, Division of Infection and Immunity, Cardiff University School of Medicine, Cardiff, United Kingdom; ${ }^{4}$ Pfizer Inc, Collegeville, PA; ${ }^{5}$ Pfizer Inc, Groton, CT, United States; ${ }^{6}$ Quintiles, Saint-Laurent, QC, Canada; ${ }^{7}$ Giesel School of Medicine at Dartmouth, Lebanon, NH, United States

Background: Rheumatoid arthritis (RA) patients (pts) are at increased risk of herpes zoster $(\mathrm{HZ})$. The most recent ACR guidelines of 2015 recommend vaccination in pts aged $\geq 50$ years prior to starting biologic DMARDs or tofacitinib, ${ }^{1}$ 